Published in final edited form as:

Prostaglandins Other Lipid Mediat. 2012 January ; 97(0): 22-28. doi:10.1016/j.prostaglandins. 2011.07.006.

\title{
Hematopoietic prostaglandin D synthase (HPGDS): a high stability, Val187lle isoenzyme common among African Americans and its relationship to risk for colorectal cancer
}

\author{
Brigette L. Tippin ${ }^{\mathrm{a}}$, A. Joan Levine ${ }^{\mathrm{c}}$, Alicia M. Materi ${ }^{\mathrm{a}}$, Wen-Liang Song ${ }^{\mathrm{d}}$, Temitope 0. \\ $\mathrm{Keku}^{\mathrm{e}}$, Julie E. Goodman ${ }^{f}$, Leah B. Sansburyg,h, Sudipto Dasi, Aihua Dai ${ }^{\mathrm{a}}$, Alan M. Kwong ${ }^{\mathrm{a}}$, \\ Amy M. Lin ${ }^{\mathrm{a}}$, John M. Lin ${ }^{\mathrm{a}}$, Jae Man Park ${ }^{\mathrm{a}}$, Ruth E. Patterson', Rowan T. Chlebowski ${ }^{\mathrm{b}}$, R. \\ Michael Garavito $^{k}$, Tsuyoshi Inoue ${ }^{l}$, Wonhwa Cho ${ }^{i}$, John A. Lawson ${ }^{d}$, Shiv Kapoor ${ }^{d}$, \\ Laurence N. Kolonel $^{\mathrm{m}}$, Loïc Le Marchand ${ }^{\mathrm{m}}$, Robert W. Haile ${ }^{\mathrm{c}}$, Robert S. Sandler ${ }^{\mathrm{g}}$, and Henry \\ J. Lin ${ }^{a},{ }^{*}$ \\ aDivision of Medical Genetics, Harbor-UCLA Medical Center and Los Angeles Biomedical \\ Research Institute, Torrance, California \\ ${ }^{b}$ Division of Medical Oncology and Hematology, Harbor-UCLA Medical Center and Los Angeles \\ Biomedical Research Institute, Torrance, California
}

'Department of Preventive Medicine, University of Southern California School of Medicine, Los Angeles, California

dThe Institute for Translational Medicine and Therapeutics, The University of Pennsylvania, Philadelphia, Pennsylvania

eDivision of Gastroenterology and Hepatology, Department of Medicine, University of North Carolina, Chapel Hill, North Carolina

fLaboratory of Human Carcinogenesis, National Cancer Institute, Bethesda, Maryland (current address, Gradient, Cambridge, Massachusetts)

${ }^{g}$ Center for Gastrointestinal Biology and Disease, Division of Gastroenterology and Hepatology, School of Medicine, University of North Carolina, Chapel Hill, North Carolina

'Department of Chemistry, University of Illinois at Chicago, Illinois

iCancer Prevention Program, Fred Hutchinson Cancer Research Center, Seattle, Washington (current address, Moores UCSD Cancer Center, University of California, San Diego, La Jolla, California

kDepartment of Biochemistry and Molecular Biology, Michigan State University, East Lansing, Michigan

'Department of Materials Chemistry, Graduate School of Engineering, Osaka University, Osaka, Japan

mUniversity of Hawaii Cancer Center, Honolulu, Hawaii

\footnotetext{
(c) 2011 Elsevier Inc. All rights reserved.

"Corresponding author. Tel.: +1 310222 3756; fax: +1 310328 9921. hlin@labiomed.org (H. J. Lin).

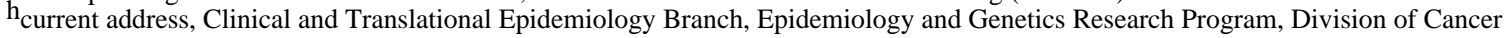
Control and Population Sciences, National Cancer Institute, Bethesda, Maryland

Publisher's Disclaimer: This is a PDF file of an unedited manuscript that has been accepted for publication. As a service to our customers we are providing this early version of the manuscript. The manuscript will undergo copyediting, typesetting, and review of the resulting proof before it is published in its final citable form. Please note that during the production process errors may be discovered which could affect the content, and all legal disclaimers that apply to the journal pertain.
} 


\section{Abstract}

Intestinal tumors in $A p c^{\mathrm{Min} /+}$ mice are suppressed by over-production of HPGDS, which is a glutathione transferase that forms prostaglandin $\mathrm{D}_{2}\left(\mathrm{PGD}_{2}\right)$. We characterized naturally occurring HPGDS isoenzymes, to see if HPGDS variation is associated with human colorectal cancer risk. We used DNA heteroduplex analysis and sequencing to identify HPGDS variants among healthy individuals. HPGDS isoenzymes were produced in bacteria, and their catalytic activities were tested. To determine in vivo effects, we conducted pooled case-control analyses to assess whether there is an association of the isoenzyme with colorectal cancer. Roughly 8\% of African Americans and $2 \%$ of Caucasians had a highly stable Val187lle isoenzyme (with isoleucine instead of valine at position 187). At $37^{\circ} \mathrm{C}$, the wild-type enzyme lost $15 \%$ of its activity in one hour, whereas the Val187Ile form remained $>95 \%$ active. At $50^{\circ} \mathrm{C}$, the half life of native HPGDS was 9 minutes, compared to 42 minutes for Val187Ile. The odds ratio for colorectal cancer among African Americans with Val187Ile was 1.10 (95\% CI, 0.75-1.62; 533 cases, 795 controls). Thus, the Val187Ile HPGDS isoenzyme common among African Americans is not associated with colorectal cancer risk. Other approaches will be needed to establish a role for HPGDS in occurrence of human intestinal tumors, as indicated by a mouse model.

\section{Keywords}

glutathione transferase; HPGDS; prostaglandin $\mathrm{D}_{2}$; colon cancer

\section{Introduction}

D series prostaglandins were discovered 40 years ago [1], and prostaglandin $\mathrm{D}_{2}\left(\mathrm{PGD}_{2}\right)$ has since proven to be a mediator of sleep [2,3], platelet aggregation, inflammation, smooth muscle contraction, and allergic asthma [4]. Hematopoietic prostaglandin D synthase (HPGDS; NCBI Gene ID 27306) converts $\mathrm{PGH}_{2}$ to $\mathrm{PGD}_{2}$, and the enzyme is also a $\sigma$ class glutathione transferase [5, 6]. HPGDS was originally found in the rat spleen [7-11] and later in other tissues [12, 13]. The 3-dimensional structure of HPGDS has been defined for possible drug targeting, due to involvement of HPGDS in allergic asthma and inflammation [14].

Tumor-prone $A p c^{\mathrm{Min} /+}$ mice deficient in HPGDS developed 50\% more intestinal adenomas compared to controls. Conversely, $A p c^{\mathrm{Min} /+}$ mice that over-produced the enzyme from $H P G D S$ transgenes had $70 \%$ fewer tumors [15]. The concept of $\mathrm{PGD}_{2}$ as a tumor suppressing molecule is supported by faster growth of Lewis lung cancer cells implanted onto mice that lack PTGDR [16]. Here we describe a high stability, Val187Ile HPGDS isoenzyme among African Americans and assess its impact on colorectal tumors.

\section{Materials and methods}

\subsection{Identification of gene variants [17]}

We used blood specimens from the UCLA Tissue Typing Laboratory to identify common $H P G D S$ variants. One mm squares of dried blood on blotter paper served as PCR templates (903 paper; Whatman GE Healthcare; Piscataway, NJ). We used DNA heteroduplex analysis to screen for variants in exons and flanking intron regions in 47 African American and 47 white subjects. DNA sequencing identified the base substitutions. Last, we used allelespecific PCR to search for these substitutions in other ethnic groups [Chinese (Hong Kong), Filipino, Hispanic, Indian (Asian), Japanese, Korean, and Samoan). PCR primers are shown in Table S1. 


\subsection{HPGDS expression vectors and mutagenesis}

We prepared a human HPGDS coding fragment by use of PCR, with human spleen cDNA as the template (Clontech; Mountain View, CA). PCR primers were: 5'-TAT ACA TAT GCC AAA CTA CAA ACT CAC T-3' (HPGDS-L14B) and 5'-TAT AGG ATC CCT AGA GTT TGG TTT GGG G-3' (HPGDS-R12). Primer L14B contained an NdeI restriction site (CATATG) and a total of 21 nucleotides of the HPGDS sequence, beginning with the ATG start site. Primer R12 contained 18 nucleotides of HPGDS (up to and including the TAG stop codon), followed by a BamHI site (GGA TCC). We subcloned the PCR product between NdeI and BamHI restriction sites in a bacterial plasmid (pET-5a; Novagen EMD Biosciences, Inc.; San Diego, CA), introduced selected mutations (QuikChange site-directed mutagenesis; Stratagene; La Jolla, CA), and checked the final plasmids by sequencing. Mutagenic oligonucleotides were: 5'-GGA ACA ATG TCA TGT TGA TGC TGT TGT GGA CAC TCT GG-3' and 5'-CCA GAG TGT CCA CAA CAG CAT CAA CAT GAC ATT GTT CC-3' (for Ile91Val); 5'-GCT CAC GTA TAA TGC GCC TCA TCT TAC GCA AGA CTT GG-3' and 5'-CCA AGT CTT GCG TAA GAT GAG GCG CAT TAT ACG TGA GC-3' (for Met128Thr); 5'-CCA AGC CAT TCC TGC CAT CGC TAA CTG GAT AAA ACG-3' and 5'-CGT TTT ATC CAG TTA GCG ATG GCA GGA ATG GCT TGG-3' (for Val187Ile).

\subsection{Biochemical characterization of HPGDS isoenzymes}

HPGDS isoenzymes were produced in E. coli strain BL21 (DE3; Stratagene). Cells were grown in L-broth with ampicillin to an absorbance of 0.7 at $600 \mathrm{~nm}$ and then induced with IPTG. Cells were suspended in phosphate buffered saline (PBS) with $5 \mathrm{mM}$ dithiothreitol (DTT) and lysed with lysozyme $(0.5 \mathrm{mg} / \mathrm{ml})$ while stirring for 30 minutes at $4{ }^{\circ} \mathrm{C}$. We recovered soluble proteins by centrifugation $\left(12,000 \mathrm{rpm}\right.$ in a GSA rotor at $\left.4{ }^{\circ} \mathrm{C}\right)$. Ammonium sulfate was added to a concentration of $60 \%$ saturation. Pellets were resuspended in PBS with $5 \mathrm{mM}$ DTT and $5 \mathrm{mM} \mathrm{MgCl}_{2}$ (buffer 2) and then loaded onto a Sephadex G-75 column (GE Healthcare). Peak fractions containing HPGDS were pooled and loaded onto a glutathione-agarose column (Sigma-Aldrich; St. Louis, MO), washed with 3 column volumes of buffer 2, and eluted with 2 column volumes of fresh $50 \mathrm{mM}$ Tris-Cl pH 9.0 with $10 \mathrm{mM}$ reduced glutathione. Peak fractions were dialyzed into $50 \mathrm{mM} \mathrm{NaPO}_{4}$ (pH 7.0) containing $10 \%$ glycerol at $4{ }^{\circ} \mathrm{C}$, aliquoted, and stored at $-80{ }^{\circ} \mathrm{C}$.

We measured glutathione transferase activity of HPGDS enzymes with 1-chloro-2,4dinitrobenzene (CDNB) as substrate [18]. PGD $_{2}$ synthesizing activity was measured with $\left[1-{ }^{14} \mathrm{C}\right] \mathrm{PGH}_{2}$ as substrate [19].

\subsection{Modeling of the 3-dimensional structure of the HPGDS Val187lle variant}

Molecular modeling of the variant enzyme was based on the crystal structure of native, $\mathrm{Mg}^{2+}$-bound HPGDS at 1.8 A resolution (PDB entries 1IYI and IIYH; $[14,20]$ ). We used the software package, 'O,' to select the most stable rotamer of residue Ile187 [21]. CNS programs [20] were used to obtain an energy-minimized model of the mutant enzyme, without unfavorable contacts associated with the $\mathrm{C}_{\delta}$ atom of Ile187.

\subsection{Epidemiologic studies of colorectal neoplasia}

We used data on African Americans in 6 published case-control studies in analyses of the HPGDS Val187Ile variant. For adenomas, we used the University of Southern California/ Kaiser sigmoidoscopy study [USC/Kaiser; 22] and the University of North Carolina Diet and Health Study III [UNC DHS III; 23]. For cancer, we used the Multiethnic Cohort Study [MECS; 24], the Women's Health Initiative observational study [WHI; 25], and the North Carolina Colorectal Cancer Study 1 [NCCCS1; 26, 27] and Study 2 [NCCCS2; 28]. For the 
WHI subjects, we matched the available African American colorectal cancer cases (50) to 3 controls each (from among a total of 6,534 controls), according to baseline age and followup time.

Dried blood spots on blotter paper or DNA samples in solution were tested for Val187Ile, by use of allele-specific PCR. Samples from USC/Kaiser, UNC DHS III, MECS, and WHI were tested in duplicate and then re-tested, if initial results were unclear. Samples from NCCCS1 and NCCCS2 had an initial test and then re-testing, if the initial result was unclear or to confirm presence of the Val187Ile variant. A randomly chosen quality control subset (10\% of NCCCS1) showed $100 \%$ consistency with assigned genotypes.

Additionally, we analyzed a variant of prostaglandin-endoperoxide synthase 2 (PTGS2) -an enzyme that precedes HPGDS in $\mathrm{PGD}_{2}$ biosynthesis. We used the 4 cancer studies listed above and a genetic epidemiology study of colorectal cancer in Baltimore [29].

To quantify the heterogeneity between studies, we used Cochran's $Q$ parameter and the associated $P$-value, by the use of Stata 10 (StataCorp LP, College Station, TX). Odds ratios (ORs) and 95\% confidence intervals (CIs) were calculated by unconditional logistic regression, comparing Val187Ile carriers to wild-type subjects (Val/Val) for HPGDS analyses and Val511Ala carriers to wild-type subjects (Val/Val) for PTGS2 analyses (SAS version 9.1; SAS Institute; Carey, NC). We adjusted ORs for age (within 5-year intervals) and gender in the individual studies (except WHI) and for age, gender, and study site in combined analyses. Variables were retained in logistic regression models if omitting them changed the OR estimate by at least $10 \%$. Adjustment for body mass index gave the same results as those without adjustment. Therefore, we omitted body mass index from the analyses. All $P$-values were 2 -sided, and values $<0.05$ were considered statistically significant.

\subsection{Results and discussion}

\subsection{HPGDS variants (Table 1)}

Six DNA variants were identified, and 3 of them changed the amino acid sequence:

Ile91Val, Met128Thr, and Val187Ile (reported in [6]). One substitution in the coding region did not change an amino acid (c.597 C>G), and there were 2 intron variants (IVS2+11 A $>C$, IVS3+13 T $>C$ [30]). Variants that changed the amino acid sequence were evaluated further.

Val187Ile allele frequencies were 0.044 among healthy African Americans $(106 / 2,386)$ and 0.010 among healthy whites (3/294; Table 1). Val187Ile was not detected among small samples of Chinese (Hong Kong), Hispanics, Asian Indians, Japanese, Koreans (25 individuals each), or Samoans (24 individuals). Three white specimens (from the UCLA Tissue Typing Laboratory), 2 African American specimens (from the North Carolina DHS III study), and one Filipino specimen (out of 25 from the UCLA Tissue Typing Laboratory) had all 3 substitutions (Ile91Val, Met128Thr, and Val187Ile), indicating an allele with at least 2 of the nucleotide changes.

\subsection{Stabilities of HPGDS isoenzymes}

We observed weak affinity of human HPGDS for glutathione agarose during purification [6, 31 , leading to low recovery of enzymes from $E$. coli despite high expression from plasmid vectors. However, we obtained adequate amounts of purified enzymes by increasing the amounts of $\mathrm{MgCl}_{2}$ and DTT in the binding buffer.

Glutathione transferase specific activities at room temperature were: wild-type, $5.8 \pm 0.2$; Val187Ile, $4.7 \pm 0.5$; Ile91 Val, $4.2 \pm 0.1 ;$ Met128Thr, $3.0 \pm 0.1 \mu \mathrm{mol} / \mathrm{min} / \mathrm{mg}$ of protein 
(mean \pm standard error; 3 determinations). Prostaglandin D synthase specific activities followed the same order: wild-type, 17.3; Val187Ile, 20.4; Ile91Val, 18.6; Met128Thr, 10.5 $\mu \mathrm{mol} / \mathrm{min} / \mathrm{mg}$ of protein (single measurements with radio-labeled $\mathrm{PGH}_{2}$ at $37^{\circ} \mathrm{C}$ ). Met128Thr converts a hydrophobic thioether side chain to a hydrophilic side chain. The change occurs between 2 conserved residues in a hydrophobic cavity at the dimer interface (Leu127, Asp130) [5, 6].

Thermal stabilities of HPGDS variants were first evaluated by use of glutathione transferase assays. The half-life of the Val187Ile variant increased $>4$-fold to 42 minutes at $50{ }^{\circ} \mathrm{C}$, compared to 9 minutes for the wild-type (Fig. 1A). High stability was found with 3 independent enzyme preparations of the wild type and Val187Ile variant and thus was not due to purification differences.

Similarly, Val187Ile had higher stability when $\mathrm{PGD}_{2}$ synthesis activity was measured. Specifically, at $50^{\circ} \mathrm{C}$, the half-life for wild-type $\mathrm{PGD}_{2}$ synthesis activity was 14 minutes, whereas the Val187Ile variant retained $95 \%$ of its activity over this interval (Fig. 1B). In contrast, the Ile91 Val and Met128Thr variants lost half of their activities by 6 minutes at 50 ${ }^{\circ} \mathrm{C}$ (Fig. 1B). At $37^{\circ} \mathrm{C}$, the wild-type enzyme lost $15 \%$ of its activity in one hour, whereas Val187Ile remained $>95 \%$ active (Fig. 1C). The Val187Ile allele was in the HPGDS clone expressed by Jowsey et al. [6], but enzyme stability was not reported.

\subsection{3-Dimensional structure of the Val187lle isoenzyme}

Residue 187 lies in the N-terminal portion of helix-9, far from the catalytic and dimerization domains of the enzyme. In native HPGDS, helix-9 and its adjoining C-terminal loop are held in place by one van der Waals and 7 hydrogen bonding interactions. However, there are 3 more van der Waals interactions in the variant enzyme (Figs. 1D-E). These interactions are likely to reduce mobility of helix-9 and of the outer regions of the enzyme.

\subsection{Case-control analyses of the HPGDS Val187lle variant and colorectal tumors}

Highly expressed transgenic HPGDS enzymes inhibit intestinal adenomas in $A p c^{\mathrm{Min} /+}$ mice [15]. Therefore, we did case-control analyses to see if the highly stable HPGDS isoenzyme prevents colorectal tumors in humans. As described in section 2.5, we used DNA and data from 6 published studies of colorectal tumors. Subjects in these studies were characterized by age, gender, body mass index, and NSAID usage (Table S2).

The OR for colorectal cancer with the Val187Ile variant (versus wild-type Val/Val) was 1.10 (95\% CI, 0.75-1.62; 533 cases and 795 controls). Similarly, the OR for colorectal adenomas was 0.93 (95\% CI, 0.46-1.86; 161 cases and 219 controls). Thus, there was no change in risk for colorectal tumors with Val187Ile (Table 2).

Strengths of the analyses were population-based cases and controls in the Multiethnic Cohort, North Carolina, and WHI studies. The USC/Kaiser sigmoidoscopy-based study screened asymptomatic individuals for a first diagnosis of adenomas, but $15-20 \%$ of individuals with no polyp by sigmoidoscopy may have adenomas more proximally [32]. A limitation was low prevalence of Val187Ile. Specifically, the combined colorectal cancer studies had $80 \%$ power to detect an OR of $\sim 0.5$. Larger samples are needed to exclude weaker associations.

We also measured excretion of 11,15-dioxo-9a-hydroxy-2, 3, 4, 5-tetranorprostan-1,20dioic acid (tetranor PGDM) in relation to Val187Ile in a pilot study of healthy African American volunteers. Tetranor PGDM is the most abundant urinary metabolite of $\mathrm{PGD}_{2}$ [33]. Median values of urinary tetranor PGDM (in $\mathrm{ng} / \mathrm{mg}$ of creatinine) were 5.16 for controls (18 individuals; mean age, 35.4 years) and 6.68 for Val187Ile carriers (5 
individuals; mean age, 39.2). The results indicate no difference in tetranor PGDM excretion for Val187Ile carriers and controls ( $P=0.48$, Mann-Whitney; data not shown). However, the study was limited by difficulties in recruiting non-smokers (i.e., subjects with undetectable urine cotinine). Smoking induces PTGS2 [34], which in turn produces $\mathrm{PGH}_{2}$ (the substrate for HPGDS) -- thereby potentially raising $\mathrm{PGD}_{2}$ metabolite levels. Larger studies are needed for a definitive interpretation.

\subsection{Case-control analyses of the PTGS2 Val511Ala variant}

We considered whether variants of phospholipase $\mathrm{A}_{2}$ (group IVA; PLA2G4A) and PTGS2 -- 2 enzymes that precede HPGDS in PGD $_{2}$ biosynthesis -- might influence HPGDS effects. We found no DNA variant that changes the PLA2G4A amino acid sequence among 45 blood specimens from healthy African Americans (Table S3).

For PTGS2, Fritsche et al. [35] reported a variant -- alanine replacing valine at residue 511 -- that has the potential to alter the cyclooxygenase active site (Fig. S1; rs5273; [17]). Enzyme assays showed no differences in catalytic function of the Val511Ala variant, when measured with arachidonic acid, linoleic acid, or 2-arachidonyl glycerol as substrates. However, PTGSs can also convert various endogenous or dietary fatty acids to different prostanoid products [36], such as series 1 and 3 prostaglandins. Moreover, PTGS2 that has been acetylated by aspirin converts arachidonic acid into 15-epi-lipoxin, rather than $\mathrm{PGH}_{2}$ [37]. Several mutations in the cyclooxygenase active site of PTGSs can also result in production of non-prostanoid compounds [38].

The Val511Ala PTGS2 isoenzyme occurs among 8-10\% of African Americans. There were (non-statistically significant) inverse associations for colon cancer or adenomas among individuals who were Val511Ala carriers and/or users of nonsteroidal anti-inflammatory drugs (NSAIDs) [17, 26].

Therefore, we produced new data from WHI and NCCCS2 subjects and combined them with all published data in Tables S4 and S5 [17, 26, 29]. However, we found no association with colorectal cancer in relation to the PTGS2 variant (Val511Ala carriers versus wild-type $\mathrm{Val} /$ Val subjects; overall OR, 0.77; 95\% CI, 0.52-1.13; 704 cases and 1,038 controls; Table S5A).

We also analyzed Val511Ala apart from NSAID usage and in combination with NSAID use, in order to assess for interaction between Val511Ala and NSAIDs. Among all subjects, the OR for colorectal cancer among NSAID users was 0.80 (95\% CI, 0.63-1.01; Table S5B), indicating no preventive effect in this study population. Results were similar when individuals with Val511Ala were excluded (OR, 0.85; 95\% CI, 0.66-1.09; Table S5B). Among NSAID non-users, the OR for subjects with Val511Ala versus wild-type subjects was 0.95 (95\% CI, 0.57-1.57; Table S5C), indicating no effect of Val511Ala apart from NSAID use. Finally, compared to wild-type individuals who were non-users, the OR was 0.41 (95\% CI, 0.18-0.92; Table S5D) for individuals who had Val511Ala and were users. However, numbers of subjects in this group were small ( 8 cases and 27 controls), and there was no statistical interaction between NSAID use and Val511Ala $(P=0.17)$.

These analyses show no association between Val511Ala and risk for colorectal cancer. Strengths of the analyses include the high quality of subject ascertainment and data collection, including 3 population-based studies. However, more subjects are needed to exclude low level associations. The pooled data had $80 \%$ power to detect an OR for cancer of $\sim 0.5$. Other limitations were lack of NSAID data for $20 \%$ of individuals ( 119 cases; 222 controls) and varying definitions of NSAID use. 
We also evaluated prostaglandin production in relation to Val511Ala among healthy African Americans and found no change in $\mathrm{PGE}_{2}$ production (by peripheral blood monocytes) or excretion of PGE-M and PGI-M by 4 healthy Val511Ala carriers (not shown) [39]. Taken together, the data support an interpretation that the PTGS2 Val511Ala variant is not phenotypically important.

\subsection{Comparison of the Val187lle variant to HPGDS transgenes and knockouts in mice}

As mentioned in the introduction, $A p c^{\mathrm{Min} /+}$ mice with human HPGDS transgenes had 70\% fewer intestinal adenomas. In these mice, the human HPGDS transgene (driven by a strong constitutive promoter) produced 375 times more mRNA transcripts than were found for the endogenous mouse $H p g d s$ genes [15]. Conversely, $A p c^{\mathrm{Min} /+}$ mice with heterozygous or homozygous Hpgds gene knockouts had 50\% more tumors compared to controls. These mice should produce at least 50\% less HPGDS in expressing cells.

In contrast to these mutations introduced in mice, the Val187Ile variant should mainly affect removal of HPGDS, rather than production. Historically, rates of heat inactivation of enzymes in vitro correlated roughly with enzyme half-lives in vivo [40]. A 15\% loss of wild-type HPGDS activity in one hour at $37^{\circ} \mathrm{C}$ (Fig. 1C) corresponds to a half-life for unfolding of 4.3 hours. The half-life for unfolding of the Val187Ile enzyme at $37^{\circ} \mathrm{C}$ may then be 20 hours, as estimated from comparison of the half-lives at $50{ }^{\circ} \mathrm{C}(42$ minutes for Val187Ile versus 9 minutes for wild-type HPGDS; Fig. 1A).

During the first half-life after HPGDS production in cells that are heterozygous for Val187Ile, the average ratio of the level of the Val187Ile isoenzyme to the level of wild-type HPGDS may be only 1.3 to 1 , as estimated from half-lives for unfolding and exponential decay. This ratio corresponds to only a 1.15 -fold increase in the HPGDS level [or $(1+1.3)$ / 2]. Thus, the amount of lingering HPGDS is expected to be much less than produced from a 375-fold overexpressed HPGDS transgene in mice.

Degradation of intracellular proteins can also be regulated by the ubiquitin/proteasome system [41, 42]. For example, PTGS2 is removed by the ubiquitin system and has a half-life of 3.5 to 8 hours in colon cancer cells [43]. A 19-amino acid segment located 6 residues from the C-terminus targets PTGS2 for proteasomal degradation [44]. On the other hand, PTGS1 is constitutively produced in many tissues and has a long half-life (>12 hours). (PTGS1 is the major source of $\mathrm{PGH}_{2}$ for $\mathrm{PGD}_{2}$ production under normal conditions [33].) However, there are no data on ubiquitin and HPGDS.

It seems likely that the lack of a tumor suppressing effect of the Val187Ile isoenzyme may be due to inadequate amounts of HPGDS, compared to amounts found in HPGDS transgenic mice. Thus, results of our case-control studies on Val187Ile are compatible with an interpretation that high levels of $\mathrm{PGD}_{2}$ may be needed to suppress intestinal tumors, assuming that the mouse results represent $\mathrm{PGD}_{2}$ effects in humans. However, because our data can only exclude protective effects with ORs $<0.5$ (section 3.5), low statistical power may also be a reason for lack of a detectable effect of the variant.

\subsection{Other approaches to studies of $\mathrm{PGD}_{2}$ and colorectal cancer}

Other bioactive molecules that influence $\mathrm{PGD}_{2}$ effects include prostaglandin catabolizing enzymes and $\mathrm{PGD}_{2}$ receptors. 15-Hydroxyprostaglandin dehydrogenase (15-PGDH) is recognized as a major enzyme for prostaglandin degradation, but $\mathrm{PGD}_{2}$ is a poor substrate for the enzyme [45]. Alternatively, the $\mathrm{PGD}_{2}$ receptor, PTGDR (also known as DP1; Gene ID 5729) appears to be involved in growth of intestinal tumors. For example, Gustaffson et al. found 5-fold lower expression of PTGDR in colorectal cancers, compared to normal tissues (62 tumors and 43 normal tissues, from 62 patients [46]). Galamb et al. observed 
decreasing PTGDR expression going from normal tissues, to adenomas, to early cancers (Dukes A, B), and to advanced cancers (Dukes C, D; [47]).

Several PTGDR variants have been cataloged, including nonsense mutations (W48X and Y177X [48]). Screening for PTGDR nonsense variants may be a potential way to analyze colorectal cancer in relation to $\mathrm{PGD}_{2}$ effects by a genetic epidemiology approach. However, frequencies of the currently known nonsense alleles are very low.

\subsection{Conclusions}

A highly stable Val187Ile HPGDS variant occurs in $8 \%$ of African Americans. There was no protective effect of the variant found against colorectal cancer. Inhibition of intestinal tumors by transgenic HPGDS in $A p c^{\mathrm{Min} /+}$ mice was associated with 375-fold overexpression of HPGDS [15], which most likely produces more HPGDS than is found with Val187Ile. Therefore, although the naturally occurring Val187Ile isoenzyme differs biochemically from the wild-type enzyme and is fairly common among African Americans, other studies will be needed to establish a role for $\mathrm{PGD}_{2}$ in development of intestinal tumors in humans, as predicted from mouse models. Analysis of $\mathrm{PGD}_{2}$ receptor (PTGDR) variants may be another approach.

\section{Highlights}

> We conducted a systematic survey of naturally occurring HPGDS enzyme variants. > A high stability Val187Ile variant occurs in $8 \%$ of African Americans and 2\% of Caucasians. > Val187Ile does not protect against colon cancer. > Other methods will be needed to establish a role for HPGDS in development of human intestinal tumors, as shown by mouse model data.

\section{Supplementary Material}

Refer to Web version on PubMed Central for supplementary material.

\section{Acknowledgments}

Human studies were approved by the Harbor-UCLA institutional review board. Dr. Curtis Harris kindly provided original data (related to reference 29) that were used in our pooled analysis of the PTGS2 Val511Ala variant. Drs. Yoshihiro Urade and Kosuke Aritake (Department of Molecular Behavioral Biology, Osaka Bioscience Institute, Osaka, Japan) assisted with the PGD2 synthesis assays. Dr. Florence Lin (Department of Mathematics, University of Southern California, Los Angeles) assisted with mathematical modeling of HPGDS enzyme levels. The work was supported by: National Institutes of Health grants CA44684 (R.S.S.), CA51923 (R.W.H.), CA54281 (L.N.K.), CA66794 (R.W.H.), CA73403 (H.J.L.), CA91179 (H.J.L.), and M01 RR00425 (the General Clinical Research Center at Harbor-UCLA Medical Center). The WHI program was funded by the National Heart, Lung, and Blood Institute, U.S. Department of Health and Human Services. Investigators are listed below.

Program Office: (National Heart, Lung, and Blood Institute, Bethesda, Maryland) Elizabeth Nabel, Jacques Rossouw, Shari Ludlam, Linda Pottern, Joan McGowan, Leslie Ford, and Nancy Geller.

Clinical Coordinating Center: (Fred Hutchinson Cancer Research Center, Seattle, WA) Ross Prentice, Garnet Anderson, Andrea LaCroix, Charles L. Kooperberg, Ruth E. Patterson, Anne McTiernan; (Wake Forest University School of Medicine, Winston-Salem, NC) Sally Shumaker; (Medical Research Labs, Highland Heights, KY) Evan Stein; (University of California at San Francisco, San Francisco, CA) Steven Cummings.

Clinical Centers: (Albert Einstein College of Medicine, Bronx, NY) Sylvia Wassertheil-Smoller; (Baylor College of Medicine, Houston, TX) Jennifer Hays; (Brigham and Women's Hospital, Harvard Medical School, Boston, MA) JoAnn Manson; (Brown University, Providence, RI) Annlouise R. Assaf; (Emory University, Atlanta, GA) Lawrence Phillips; (Fred Hutchinson Cancer Research Center, Seattle, WA) Shirley Beresford; (George Washington University Medical Center, Washington, DC) Judith Hsia; (Los Angeles Biomedical Research Institute at Harbor-UCLA Medical Center, Torrance, CA) Rowan Chlebowski; (Kaiser Permanente Center for Health 
Research, Portland, OR) Evelyn Whitlock; (Kaiser Permanente Division of Research, Oakland, CA) Bette Caan; (Medical College of Wisconsin, Milwaukee, WI) Jane Morley Kotchen; (MedStar Research Institute/Howard University, Washington, DC) Barbara V. Howard; (Northwestern University, Chicago/Evanston, IL) Linda Van Horn; (Rush Medical Center, Chicago, IL) Henry Black; (Stanford Prevention Research Center, Stanford, CA) Marcia L. Stefanick; (State University of New York at Stony Brook, Stony Brook, NY) Dorothy Lane; (The Ohio State University, Columbus, $\mathrm{OH}$ ) Rebecca Jackson; (University of Alabama at Birmingham, Birmingham, AL) Cora E. Lewis; (University of Arizona, Tucson/Phoenix, AZ) Tamsen Bassford; (University at Buffalo, Buffalo, NY) Jean Wactawski-Wende; (University of California at Davis, Sacramento, CA) John Robbins; (University of California at Irvine, CA) F. Allan Hubbell; (University of California at Los Angeles, Los Angeles, CA) Howard Judd; (University of California at San Diego, LaJolla/Chula Vista, CA) Robert D. Langer; (University of Cincinnati, Cincinnati, OH) Margery Gass; (University of Florida, Gainesville/Jacksonville, FL) Marian Limacher; (University of Hawaii, Honolulu, HI) David Curb; (University of Iowa, Iowa City/Davenport, IA) Robert Wallace; (University of Massachusetts/Fallon Clinic, Worcester, MA) Judith Ockene; (University of Medicine and Dentistry of New Jersey, Newark, NJ) Norman Lasser; (University of Miami, Miami, FL) Mary Jo O'Sullivan; (University of Minnesota, Minneapolis, MN) Karen Margolis; (University of Nevada, Reno, NV) Robert Brunner; (University of North Carolina, Chapel Hill, NC) Gerardo Heiss; (University of Pittsburgh, Pittsburgh, PA) Lewis Kuller; (University of Tennessee, Memphis, TN) Karen C. Johnson; (University of Texas Health Science Center, San Antonio, TX) Robert Brzyski; (University of Wisconsin, Madison, WI) Gloria E. Sarto; (Wake Forest University School of Medicine, Winston-Salem, NC) Denise Bonds; (Wayne State University School of Medicine/Hutzel Hospital, Detroit, MI) Susan Hendrix.

\section{Abbreviations}
Apc
adenomatous polyposis coli
CDNB
1-chloro-2,4-dinitrobenzene
CI confidence interval
dbSNP
the National Center for Biotechnology Information database for single nucleotide polymorphisms
HPGDS
hematopoietic prostaglandin D synthase
Min
a mouse $A p c$ allele that causes predisposition to multiple intestinal neoplasia
NSAID nonsteroidal anti-inflammatory drug
OR
odds ratio
PGD $_{2}$
prostaglandin $\mathrm{D}_{2}$
$\mathrm{PGH}_{2}$ prostaglandin $\mathrm{H}_{2}$
PLA2G4A phospholipase $A_{2}$, group IVA (cytosolic, calcium-dependent)
PTGDR $\mathrm{PGD}_{2}$ receptor, also known as DP1
PTGS2 prostaglandin-endoperoxide synthase 2

\section{References}

1. Granström E, Lands WEM, Samuelson B. Biosynthesis of 9a,15-dihydroxy-11-ketoprost-13-enoic acid. J Biol Chem. 1968; 243:4104-4108. [PubMed: 5666951]

2. Ueno R, Ishikawa $Y$, Nakayama T, Hayaishi O. Prostaglandin $D_{2}$ induces sleep when microinjected into the preoptic area of conscious rats. Biochem Biophys Res Commun. 1982; 109:576-582. [PubMed: 6960896]

3. Pinzar E, Kanaoka Y, Inui T, Eguchi N, Urade Y, Hayaishi O. Prostaglandin D synthase gene is involved in the regulation of non-rapid eye movement sleep. Proc Natl Acad Sci USA. 2000; 97:4903-4907. [PubMed: 10781097]

4. Matsuoka T, Hirata M, Tanaka H, Takahashi Y, Murata T, Kabashima K, Sugimoto Y, Kobayashi T, Ushikubi F, Aze Y, Eguchi N, Urade Y, Yoshida N, Kimura K, Mizoguchi A, Honda Y, Nagai H, Narumiya S. Prostaglandin $\mathrm{D}_{2}$ as a mediator of allergic asthma. Science. 2000; 287:2013-2017. [PubMed: 10720327] 
5. Kanaoka Y, Ago H, Inagaki E, Nanayama T, Miyano M, Kikuno R, Fujii Y, Eguchi N, Toh H, Urade Y, Hayaishi O. Cloning and crystal structure of hematopoietic prostaglandin D synthase. Cell. 1997; 90:1085-1095. [PubMed: 9323136]

6. Jowsey IR, Thomson AM, Flanagan JU, Murdock PR, Moore GB, Meyer DJ, Murphy GJ, Smith SA, Hayes JD. Mammalian class sigma glutathione S-transferases: catalytic properties and tissuespecific expression of human and rat GSH-dependent prostaglandin $\mathrm{D}_{2}$ synthases. Biochem J. 2001; 359:507-516. [PubMed: 11672424]

7. Nugteren DH, Hazelhof E. Isolation and properties of intermediates in prostaglandin biosynthesis. Biochim Biophys Acta. 1973; 326:448-461. [PubMed: 4776443]

8. Ujihara M, Urade Y, Eguchi N, Hayashi H, Ikai K, Hayaishi O. Prostaglandin $\mathrm{D}_{2}$ formation and characterization of its synthetases in various tissues of adult rats. Arch Biochem Biophys. 1988; 260:521-531. [PubMed: 3124755]

9. Kanaoka Y, Urade Y. Hematopoietic prostaglandin D synthase. Prostaglandins Leukot Essent Fatty Acids. 2003; 69:163-167. [PubMed: 12895599]

10. Urade Y, Eguchi N. Lipocalin-type and hematopoietic prostaglandin D synthases as a novel example of functional convergence. Prostaglandins Other Lipid Mediat. 2002; 68-69:375-382.

11. Christ-Hazelhof E, Nugteren DH. Purification and characterisation of prostaglandin endoperoxide D-isomerase, a cytoplasmic, glutathione-requiring enzyme. Biochim Biophys Acta. 1979; 572:4351. [PubMed: 32914]

12. Ujihara M, Horiguchi Y, Ikai K, Urade Y. Characterization and distribution of prostaglandin D synthase in rat skin. J Invest Dermatol. 1988; 90:448-451. [PubMed: 3127478]

13. Urade Y, Ujihara M, Horiguchi Y, Ikai K, Hayaishi O. The major source of endogenous prostaglandin D2 is likely antigen-presenting cells. Localization of glutathione-requiring prostaglandin D synthetase in histiocytes, dendritic, and Kupffer cells in various rat tissues. J Immunol. 1989; 143:2982-2989. [PubMed: 2509561]

14. Inoue T, Irikura D, Okazaki N, Kinugasa S, Matsumura H, Uodome N, Yamamoto M, Kumasaka T, Miyano M, Kai Y, Urade Y. Mechanism of metal activation of human hematopoietic prostaglandin D synthase. Nat Struct Biol. 2003; 10:291-296. [PubMed: 12627223]

15. Park JM, Kanaoka Y, Eguchi N, Aritake K, Grujic S, Materi AM, Buslon VS, Tippin BL, Kwong AM, Salido E, French SW, Urade Y, Lin HJ. Hematopoietic prostaglandin D synthase suppresses adenomas in Apc ${ }^{\mathrm{Min} /+}$ mice. Cancer Res. 2007; 67:881-889. [PubMed: 17283118]

16. Murata T, Lin MI, Aritake K, Matsumoto S, Narumiya S, Ozaki H, Urade Y, Hori M, Sessa WC. Role of prostaglandin $\mathrm{D}_{2}$ receptor DP as a suppressor of tumor hyperpermeability and angiogenesis in vivo. Proc Natl Acad Sci USA. 2008; 105:20009-20014. [PubMed: 19060214]

17. Lin HJ, Lakkides KM, Keku TO, Reddy ST, Louie AD, Kau IH, Zhou H, Gim JSY, Ma HL, Matthies CF, Dai A, Huang HF, Materi AM, Lin JH, Frankl HD, Lee ER, Hardy SI, Herschman HR, Henderson BE, Kolonel LN, Le Marchand L, Garavito RM, Sandler RS, Haile RW, Smith WL. Prostaglandin H synthase 2 variant (Val511Ala) in African Americans may reduce the risk for colorectal neoplasia. Cancer Epidemiol Biomark Prev. 2002; 11:1305-1315.

18. Johansson AS, Stenberg G, Widersten M, Mannervik B. Structure-activity relationships and thermal stability of human glutathione transferase P1-1 governed by the H-site residue 105 . J Mol Biol. 1998; 278:687-698. [PubMed: 9600848]

19. Urade Y, Fujimoto N, Ujihara M, Hayaishi O. Biochemical and immunological characterization of rat spleen prostaglandin D synthetase. J Biol Chem. 1987; 262:3820-3825. [PubMed: 3102495]

20. Brünger AT, Adams PD, Clore GM, DeLano WL, Gros P, Grosse-Kunstleve RW, Jiang JS, Kuszewski J, Nilges M, Pannu NS, Read RJ, Rice LM, Simonson T, Warren GL. Crystallography and NMR system: a new software suite for macromolecular structure determination. Acta Crystallogr D Biol Crystallogr. 1998; 54:905-921. [PubMed: 9757107]

21. Jones TA, Zou J-Y, Cowan SW, Kjeldgaard M. Improved methods for building protein models in electron-density maps and the location of errors in these models. Acta Crystallogr A. 1991; 47:110-119. [PubMed: 2025413]

22. Haile RW, Witte JS, Longnecker MP, Probst-Hensch N, Chen MJ, Harper J, Frankl HD, Lee ER. A sigmoidoscopy-based case-control study of polyps: macronutrients, fiber and meat consumption. Int J Cancer. 1997; 73:497-502. [PubMed: 9389562] 
23. Martin C, Connelly A, Keku TO, Mountcastle SB, Galanko J, Woosley JT, Schliebe B, Lund PK, Sandler RS. Nonsteroidal anti-inflammatory drugs, apoptosis, and colorectal adenomas. Gastroenterology. 2002; 123:1770-1777. [PubMed: 12454832]

24. Kolonel LN, Henderson BE, Hankin JH, Nomura AMY, Wilkins LR, Pike MC, Stram DO, Monroe KR, Earle ME, Nagamine FS. A multiethnic cohort in Hawaii and Los Angeles: baseline characteristics. Am J Epidemiol. 2000; 151:346-357. [PubMed: 10695593]

25. Langer RD, White E, Lewis CE, Kotchen JM, Hendrix SL, Trevisan M. The Women's Health Initiative Observational Study: baseline characteristics of participants and reliability of baseline measures. Ann Epidemiol. 2003; 13:S107-S121. [PubMed: 14575943]

26. Sansbury LB, Millikan RC, Schroeder JC, North KE, Moorman PG, Keku TO, de Cotret AR, Player J, Sandler RS. COX-2 polymorphism, use of nonsteroidal anti-inflammatory drugs, and risk of colon cancer in African Americans (United States). Cancer Causes Control. 2006; 17:257-266. [PubMed: 16489533]

27. Keku T, Millikan R, Worley K, Winkel S, Eaton A, Biscocho L, Martin C, Sandler R. 5-10Methylenetetrahydrofolate reductase codon 677 and 1298 polymorphisms and colon cancer in African Americans and whites. Cancer Epidemiol Biomark Prev. 2002; 11:1611-1621.

28. Williams CD, Satia JA, Adair LS, Stevens J, Galanko J, Keku TO, Sandler RS. Dietary patterns, food groups, and rectal cancer risk in Whites and African-Americans. Cancer Epidemiol Biomarkers Prev. 2009; 18:1552-1561. [PubMed: 19423533]

29. Goodman JE, Bowman ED, Chanock SJ, Alberg AJ, Harris CC. Arachidonate lipoxygenase (ALOX) and cyclooxygenase (COX) polymorphisms and colon cancer risk. Carcinogenesis. 2004; 25:2467-2472. [PubMed: 15308583]

30. Noguchi E, Shibasaki M, Kamioka M, Yokouchi Y, Yamakawa-Kobayashi K, Hamaguchi H, Matsui A, Arinami TA. New polymorphisms of haematopoietic prostaglandin D synthase and human prostanoid DP receptor genes. Clin Exp All. 2002; 32:93-96.

31. Mahmud I, Ueda N, Yamaguchi H, Yamashita R, Yamamoto S, Kanaoka Y, Urade Y, Hayaishi O. Prostaglandin D synthase in human megakaryoblastic cells. J. Biol Chem. 1997; 272:2826328266. [PubMed: 9353279]

32. Lieberman DA, Weiss DG, Bond JH, Ahnen DJ, Garewal H, Chejfec G. Use of colonoscopy to screen asymptomatic adults for colorectal cancer. Veterans Affairs Cooperative Study 380. N Engl J Med. 2000; 343:162-168. [PubMed: 10900274]

33. Song WL, Wang M, Ricciotti E, Fries S, Yu Y, Grosser T, Reilly M, Lawson JA, FitzGerald GA. Tetranor PGDM, an abundant urinary metabolite reflects biosynthesis of prostaglandin $\mathrm{D}_{2}$ in mice and humans. J Biol Chem. 2008; 283:1179-1188. [PubMed: 17993463]

34. McAdam BF, Byrne D, Morrow JD, Oates JA. Contribution of cyclooxygenase- 2 to elevated biosynthesis of thromboxane $\mathrm{A}_{2}$ and prostacyclin in cigarette smokers. Circulation. 2005; 112:1024-1029. [PubMed: 16087791]

35. Fritsche E, Baek SJ, King LM, Zeldin DC, Eling TE, Bell DA. Functional characterization of cyclooxygenase-2 polymorphisms. J Pharmacol Exp Ther. 2001; 299:468-476. [PubMed: 11602656]

36. Bagga D, Wang L, Farias-Eisner R, Glaspy JA, Reddy ST. Differential effects of prostaglandin derived from $\omega-6$ and $\omega-3$ polyunsaturated fatty acids on COX-2 expression and IL-6 secretion. Proc Natl Acad Sci USA. 2003; 100:1751-1756. [PubMed: 12578976]

37. Serhan CN, Clish CB, Brannon J, Colgan SP, Chiang N, Gronert K. Novel functional sets of lipidderived mediators with antiinflammatory actions generated from omega-3 fatty acids via cyclooxygenase 2-nonsteroidal antiinflammatory drugs and transcellular processing. J Exp Med. 2000; 192:1197-1204. [PubMed: 11034610]

38. Thuresson ED, Lakkides KM, Rieke CJ, Sun Y, Wingerd BA, Micielli R, Mulichak AM, Malkowski MG, Garavito RM, Smith WL. Prostaglandin endoperoxide synthase-1: the functions of cyclooxygenase active site residues in the binding, positioning, and oxygenation of arachidonic acid. J Biol Chem. 2001; 276:10347-10357. [PubMed: 11121412]

39. Patrignani P, Panara MR, Greco A, Fusco O, Natoli C, Iacobelli S, Cipollone F, Ganci A, Créminon C, Maclouf J, Patrono C. Biochemical and pharmacological characterization of the 
cyclooxygenase activity of human blood prostaglandin endoperoxide synthases. J Pharmacol Exp Ther. 1994; 271:1705-1712. [PubMed: 7996488]

40. Goldberg AL, St John AC. Intracellular protein degradation in mammalian and bacterial cells: Part 2. Annu Rev Biochem. 1976; 45:747-803. [PubMed: 786161]

41. Schrader EK, Harstad KG, Matouschek A. Targeting proteins for degradation. Nat Chem Biol. 2009; 5:815-822. [PubMed: 19841631]

42. Ciechanover A. Intracellular protein degradation: From a vague idea thru the lysosome and the ubiquitin-proteasome system and onto human diseases and drug targeting. Biochim Biophys Acta. 2011 Mar 22.

43. Shao J, Sheng H, Inoue H, Morrow JD, DuBois RN. Regulation of constitutive cyclooxygenase-2 expression in colon carcinoma cells. J Biol Chem. 2000; 275:33951-33956. [PubMed: 10930401]

44. Mbonye UR, Wada M, Rieke CJ, Tang HY, Dewitt DL, Smith WL. The 19-amino acid cassette of cyclooxygenase- 2 mediates entry of the protein into the endoplasmic reticulum-associated degradation system. J Biol Chem. 2006; 281:35770-35778. [PubMed: 17001073]

45. Tai HH, Ensor CM, Tong M, Zhou H, Yan F. Prostaglandin catabolizing enzymes. Prostaglandins Other Lipid Mediat. 2002; 68-69:483-493.

46. Gustafsson A, Hansson E, Kressner U, Nordgren S, Andersson M, Lönnroth C, Lundholm K. Prostanoid receptor expression in colorectal cancer related to tumor stage, differentiation and progression. Acta Oncol. 2007; 46:1107-1112. [PubMed: 17943472]

47. Galamb O, Sipos F, Spisák S, Galamb B, Krenács T, Valcz G, Tulassay Z, Molnár B. Potential biomarkers of colorectal adenoma-dysplasia-carcinoma progression: mRNA expression profiling and in situ protein detection on TMAs reveal 15 sequentially upregulated and 2 downregulated genes. Cell Oncol. 2009; 31:19-29. [PubMed: 19096147]

48. www.ncbi.nlm.nih.gov/projects/SNP/snp_ref.cgi?geneId=5729

49. Bittova L, Sumandea M, Cho WA. A structure-function study of the C2 domain of cytosolic phospholipase A2. Identification of essential calcium ligands and hydrophobic membrane binding residues. J Biol Chem. 1999; 274:9665-9672. [PubMed: 10092653]

50. Clark, K.; Kulathila, R.; Koehn, J.; Rieffel, S.; Strauss, A.; Hu, SI.; Kalfoglou, M.; Szeto, D.; Lasala, D.; Sabio, M.; Wang, X.; Marshall, P. American Chemical Society Book of Abstracts. Philadelphia: 2004 Aug 22-26. Crystal structure of the cyclooxygenase-2-lumiracoxib complex. BIOL 178 (Abstract) 

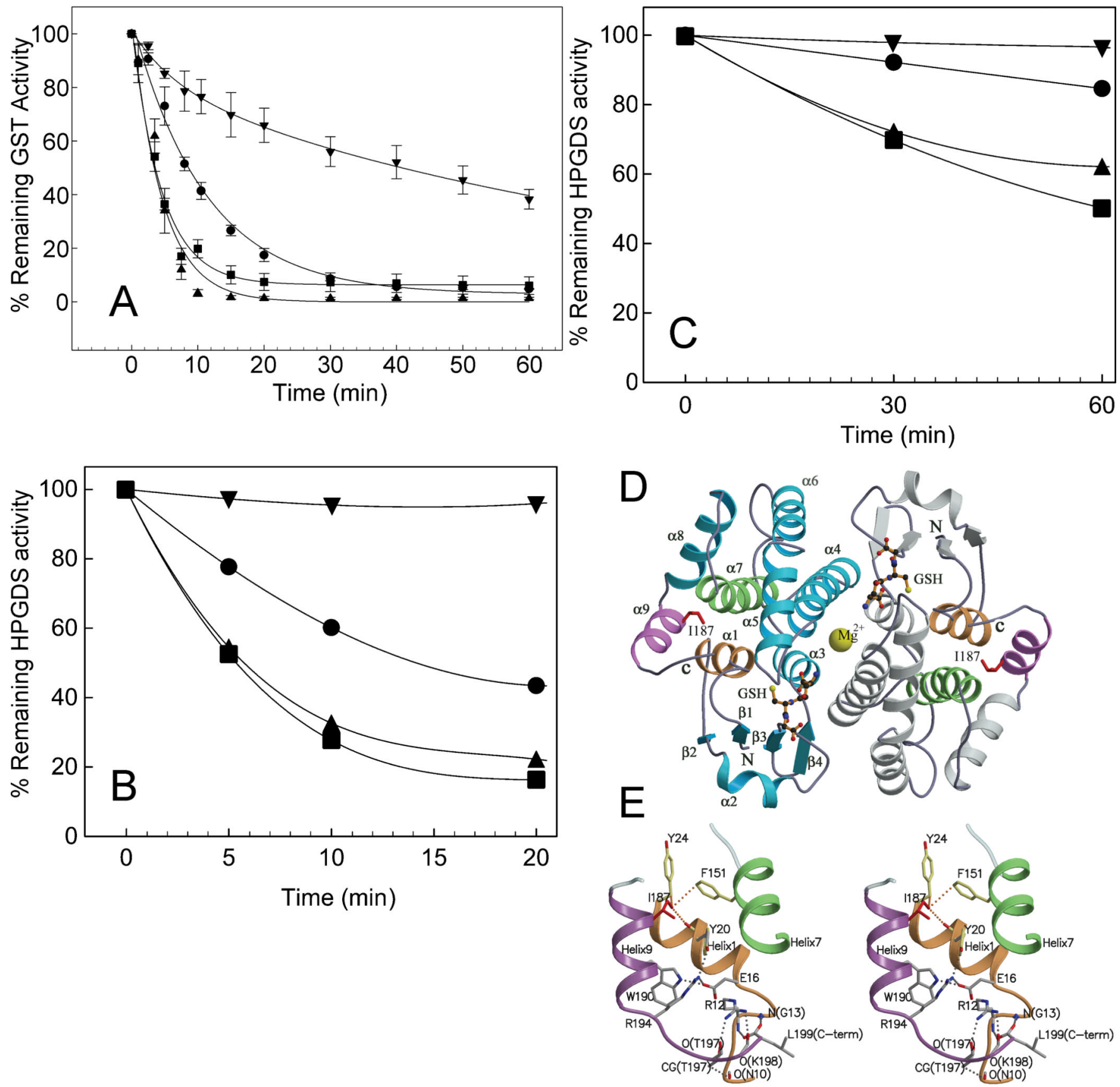

Fig. 1.

(A, B , C) Thermal stabilities of HPGDS isoenzymes. Enzymes were pre-incubated for the indicated times, followed by activity assays. Initial activities were set to $100 \%$. Symbols: $\mathbf{O}$, wild-type; $\boldsymbol{\square}$, Ile91Val; $\boldsymbol{\Delta}$, Met128Thr; $\boldsymbol{\nabla}$, Val187Ile. (A) Glutathione transferase (GST) activities at $50{ }^{\circ} \mathrm{C}$ with 1-chloro-2,4-dinitrobenzene (3 independent assays). Half-lives (minutes) were: wild-type, $8.6 \pm 0.1$; Ile91 Val, $4.3 \pm 1.9$; Met128Thr, $2.0 \pm 0.5$; Val187Ile, $41.7 \pm 9.3$ ( $P<0.05$, ANOVA with Dunnett's method). (B) $\mathrm{PGD}_{2}$ synthesis activities at 50 ${ }^{\circ} \mathrm{C}$ with radiolabeled $\mathrm{PGH}_{2}$. (C) $\mathrm{PGD}_{2}$ synthesis activities at $37{ }^{\circ} \mathrm{C}$, as in $\mathrm{B}$. (D, E) Structure of the Val187Ile isoenzyme, based on the crystal structure of native, $\mathrm{Mg}^{2+}$-bound HPGDS at $1.8 \AA$ resolution [PDB entries 1 IYI and IIYH]. (D) Ribbon drawing of dimeric HPGDS. The 
Ile187 side chain is a red stick figure in helix-9. (E) Stereo views of the region near Ile187. Added van der Waals interactions occur between the $\mathrm{C}_{\delta}$ atom of Ile 187 and the $\mathrm{O}$ (Tyr 20, $3.73 \AA$ ) , $\mathrm{C}_{\beta}$ (Tyr 24, $3.73 \AA$ ) and $\mathrm{C}_{\mathrm{S}}$ (Phe 151, $3.69 \AA$ ) atoms of nearby side chains (red dotted lines). Interaction between Ile 187 and Phe 151 is predicted to give extra stability to helix-9. 


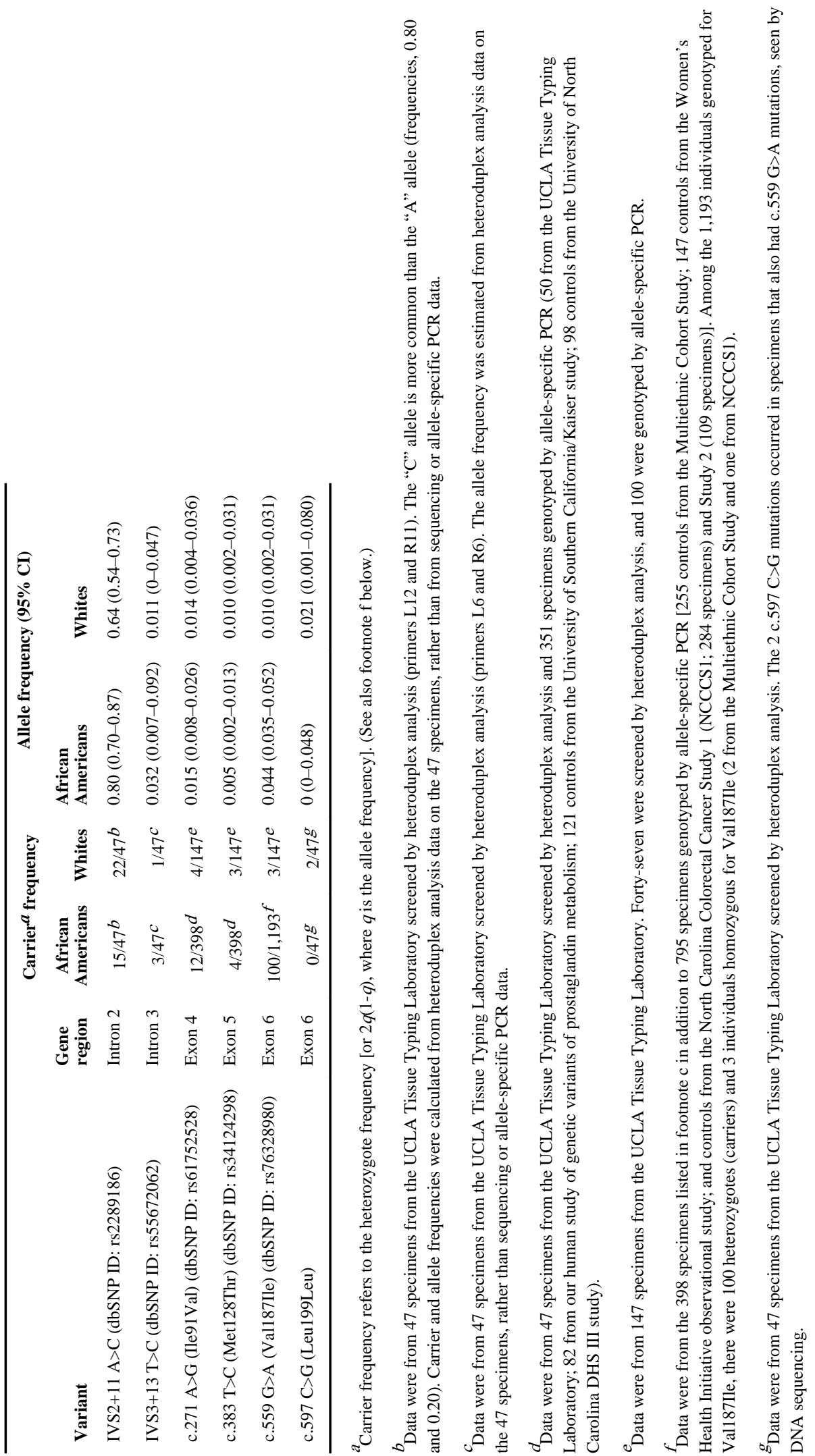




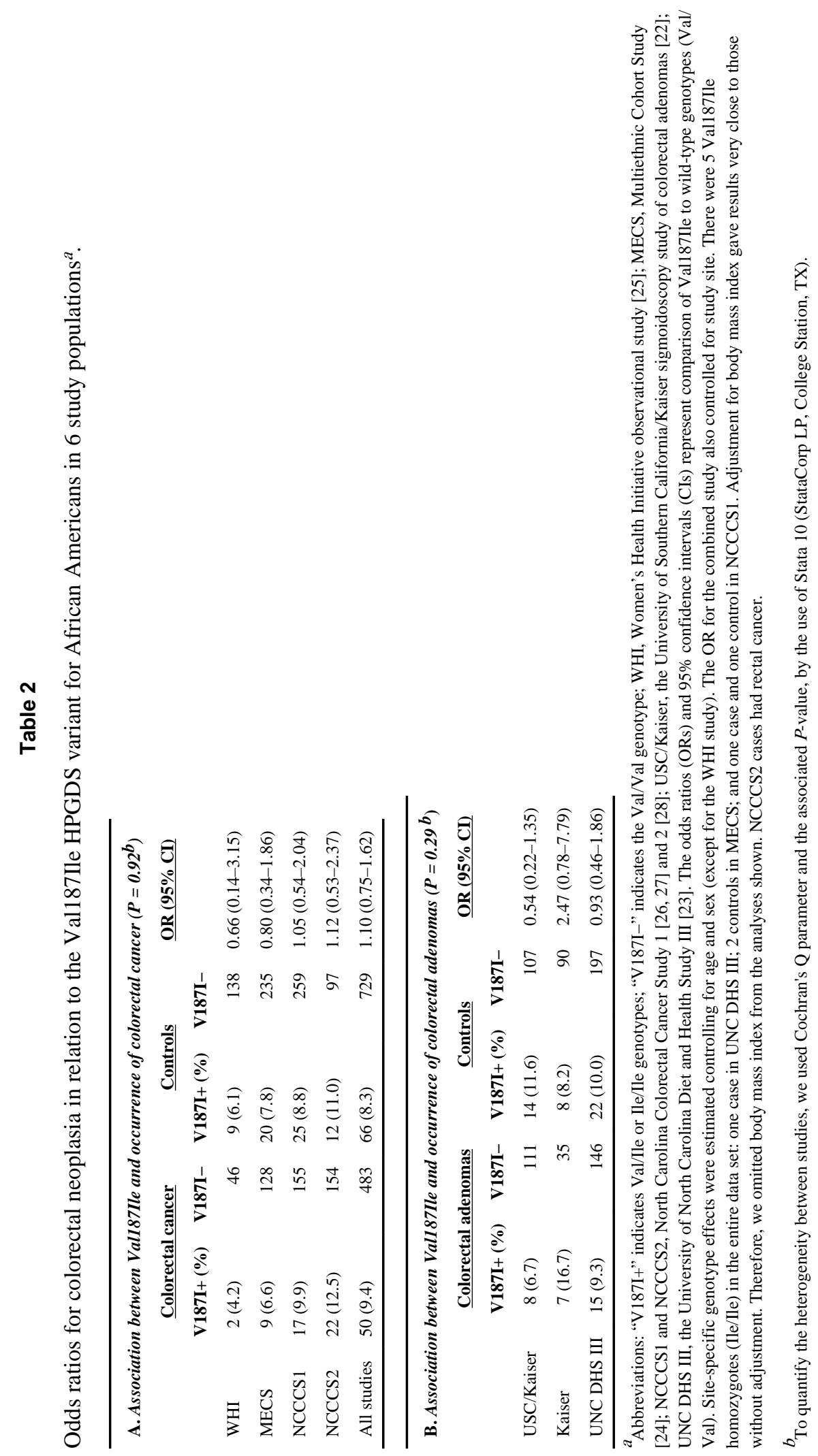

Prostaglandins Other Lipid Mediat. Author manuscript; available in PMC 2013 January 01. 